\title{
"Pseudoclusters" and typing by random amplification of polymorphic DNA of Aspergillus fumigatus
}

\author{
K.W Loudon, A P Coke, J P Burnie
}

\begin{abstract}
This short report serves as a warning to the unwary of possible "pseudoclusters" of infection with Aspergillus fumigatus as shown by the typing system, random amplification of polymorphic DNA (RAPD). This was demonstrated by typing 10 epidemiologically distinct isolates of $A$ fumigatus using two different preparations of Taq DNA polymerase. One of the enzymes did not discriminate between the isolates, giving the false impression that a cluster of infection had occurred. Enzyme source is thus a key variable when using RAPD to distinguish between isolates of $\boldsymbol{A}$ fumigatus.
\end{abstract}

(f Clin Pathol 1995;48:183-184)

Keywords: Aspergillus, RAPD typing, epidemiology.

Aspergillus fumigatus is a significant nosocomial pathogen in immunocompromised patients. It is an increasing problem as more aggressive chemotherapeutic regimens are used to treat haematological and other malignancies, rendering patients profoundly neutropenic for longer periods. ${ }^{1}$ Mortality remains high, in excess of $90 \%$, even with appropriate antifungal therapy. ${ }^{2}$ Investigation of the epidemiology and pathogenesis of the mould, therefore, has been the target of many investigators over recent years. Clusters of infection are known to be associated with building work, but in the past proving an environmental source, or that the isolates are related has been hampered by the lack of a reliable typing system. However, developments in the field of molecular biology, such as the polymerase chain reaction (PCR), have led to an increase in genotype based typing systems for the mould. ${ }^{3-6}$ One of these new techniques, random amplification of polymorphic DNA (RAPD), is a useful and relatively simple method for typing $A$ fumigatus. ${ }^{34}$ It relies on a randomly chosen short primer generating a fingerprint of the isolate by amplifying the DNA using the thermostable enzyme Taq DNA polymerase. However, variation in RAPD products has been shown to occur with changes in enzyme source for one clone of Daphnia galeata. ${ }^{7}$ This short report extends this work further to examine the effect of different enzymes on RAPD as a typing system for $A$ fumigatus. If changes in the pattern of amplified products occur, it may alter the level of discrimination of the system, and generate "pseudoclusters" amongst isolates which are actually unrelated.

\section{Methods}

Ten isolates of $A$ fumigatus were obtained from 10 cases of invasive aspergillosis occurring within the same hospital over four years.

All isolates were typed by RAPD according to the method described previously. ${ }^{3}$ The two different sources of Taq DNA polymerase were the recombinant AmpliTaq DNA polymerase from Roche and BioTaq DNA polymerase from Bioline UK Ltd. The reaction conditions were identical except that each enzyme was assayed against a range of magnesium chloride concentrations. The primer was 5' GCG CAC GG 3'.

\section{Results}

Figure 1 shows the RAPD patterns obtained from the 10 isolates with Bioline Taq DNA

\author{
Department of \\ Medical Microbiology, \\ University of \\ Manchester Medical \\ School, Oxford Road, \\ Manchester M13 9PT \\ K W Loudon \\ A P Coke \\ J P Burnie \\ Correspondence to: \\ Dr K W Loudon.

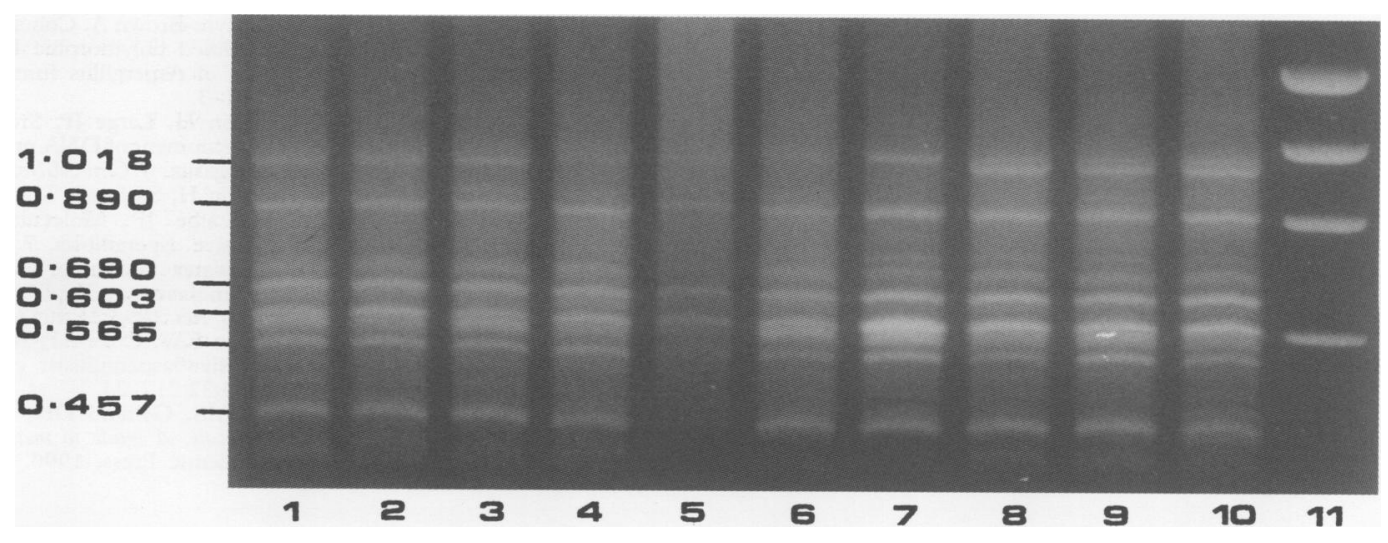

Figure 1 RAPD fingerprints generated by BioTaq polymerase. Molecular weight marker Hae III-digested $\varnothing \times 174$ (lane 11). Sizes of the RAPD products (in kilobases) are given on the left. 




Figure 2 RAPD fingerprints generated by AmpliTaq polymerase. Molecular weight marker Hae III-digested $ø \times 174$ (lane 11). Sizes of the RAPD products (in kilobases) are given on the left.

polymerase. Apart from lane 5, in which the DNA was sheared, the other nine isolates were similar. By contrast, the results obtained with AmpliTaq DNA polymerase demonstrated that there were three pairs of similar isolates; fig 2 (lanes 1 and 2, lanes 9 and 10, and lanes 3 and 5). The remaining four isolates were unique. Seven types were generated from the 10 strains. The experiments were carried out with a buffer magnesium ion concentration of $3 \mathrm{mM}$. Other magnesium ion concentrations were also tried including $1.5 \mathrm{mM}$, the concentration suggested by Bioline. At this concentration, there was no discrimination between isolates with Bioline Taq DNA polymerase, and the AmpliTaq DNA polymerase failed to work, generating only one band for all 10 isolates.

\section{Discussion}

At a magnesium ion concentration of $3 \mathrm{mM}$, the AmpliTaq DNA polymerase generated seven types from 10 isolates whilst the Bioline Taq polymerase showed no discrimination. The Bioline Taq polymerase thus suggests a "cluster" of infection, while the AmpliTaq does not. RAPD is a useful technique for typing $A$ fumigatus and has previously been used to identify a cluster of infection in patients with invasive aspergillosis. ${ }^{8}$ Whilst the technique is useful, it has limitations which must be recognised. It is well documented that Taq DNA polymerase activity has to be titrated against a range of magnesium ion concentrations to achieve optimum conditions. ${ }^{9}$ This report shows that a further key variable is the source of the enzyme. We have demonstrated that one enzyme is less discriminatory than another, suggesting isolates are similar when they are not, and generating a "pseudocluster" of infection.
This is important because if a cluster of infection is shown to have occurred, a rapid and extensive search must be made for potential sources to prevent further patients being exposed to the risk. It may be argued that further typing systems should be applied to the isolates to ensure a true cluster. However, this is time-consuming and unnecessary if the RAPD conditions have been standardised and are known to work.

In the future, it will be important to standardise the source of the Taq DNA polymerase. The present findings suggest that AmpliTaq DNA polymerase could be appropriate for RAPD typing as it is licensed, will produce good discrimination, and a high degree of reproducibility. The effect of reducing the concentration of magnesium ions is not to alter discrimination but to prevent the enzyme working.

1 Gerson SL, Talbot GH, Hurwitz S, Strom BL, Lusk EJ, Cassileth PA. Prolonged granulocytopenia; the major risk factor for invasive pulmonary aspergillosis in patients factor for invasive pulmonary aspergillosis in patients
with acute leukaemia. Ann Intern Med 1984;100:345-51.

2 Denning DW, Stevens DA. Antifungal and surgical treatment of invasive aspergillosis; review of 2121 published cases. Rev Infect Dis 1990;12:1147-201.

3 Loudon KW, Burnie JP, Cole AP, Matthews RC. Application of polymerase chain reaction to fingerprinting Aspergillus fumigatus by random amplification of polymorphic DNA f Clin Microbiol 1993;31:1117-21.

4 Aufrauvre-Brown A, Cohen J, Holden DW. Use of randomly amplified polymorphic DNA markers to distinguish isolates of Aspergillus fumigatus. $\mathcal{F}$ Clin Microbiol 1992;30 2991-3.

5 Girardin H, Latge JP, Srikantha T, Morrow B, Soll DR. Development of DNA probes for fingerprinting Aspergillus Development of DNA probes for fingerprinting
fumigatus. $₹$ Clin Microbiol 1993;31:1547-54.

6 Girardin H, Sarfati J, Traore F, Dupouy Camet J, Derouin F, Latgé JP. Molecular epidemiology of nosocomial invasive aspergillosis. $\mathcal{f}$ Clin Microbiol 1994;32:684-90.

7 Schierwater B, Ender A. Different thermostable DNA polymerase may amplify different RAPD products. Nucleic Acids Res 1993;21:4647-8.

8 Loudon KW, Coke AP, Burnie JP, Lucas GS, Liu Yin JA. Invasive aspergillosis; clusters and sources? $\mathrm{f} \mathrm{Med}$ Vet 1994;32:217-24.

9 Innis MS, Gelfand DH, Sninsky JJ, White TJ, eds. $P C R$ protocols. A guide to methods and applications. San Diego: Academic Press, 1990 